\title{
3. The power of print remains undiminished
}

TIM PANKHURST

Editor, The Dominion Post

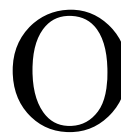

PPOSITE is the by now familiar face of former assistant police commissioner and former Auckland district commander Clint Rickards. He resigned in disgrace in December 2007 the day before internal police disciplinary charges were to begin against him.

He had survived two rape trials and escaped being convicted of any criminal offence but there was no doubt he had brought the police into disrepute through his actions in Rotorua in the 1980s, when he admitted to engaging in group sex while on duty. At the very least, he was a sexual predator and a highly intimidating bully.

He has been suspended on full pay for three years now, has earned $\$ 700,000$ in that time, has continued to drive a new car and have his petrol paid for at taxpayer expense and has kept himself busy by studying for a law degree, so on one hand he hasn't done too badly.

But his career is in tatters and rightly so, notwithstanding his very angry attempts to justify himself. This man would likely have been New Zealand's police commissioner today were it not for The Dominion Post's dramatic investigation of nearly four years ago.

It was in January 2004 that we published the sensational story of Louise Nicholas, headlined 'Police raped me'. It was clearly defamatory, the most defamatory thing that we had ever done, and our only defence could be truth. The story was so detailed, so well researched and so explosive that the next day the Prime Minister announced an inquiry into all aspects of police culture.

This led to other claimants coming forward and the result was that two of Rickards' former Rotorua police mates-Brad Shipton and Rob Schollum - are in jail for a separate rape and the man who covered up the internal police investigation, John Dewar, was in 2007 jailed for perverting the course of justice.

Louise Nicholas published her story after the trials were concluded 
and it remains on New Zealand's bestseller lists. It is central to the craft of investigative journalism.

In the book Nicholas says, 'If nothing else, the whole series of trials, ending with a bent cop's conviction, will have proven that if you step out of line you will get caught, whether it's straight away or years down the track: the error of your ways will come back and bite you on the arse.' (She does speak colloquially, Louise, bless her. It's an extremely well written book.) To that I would add the rider: but only if you are as tough and determined as Louise Nicholas, as professional and driven as reporter Phil Kitchin and as fearless as The Dominion Post.

One of the joys of being a metropolitan editor is that you get to present to the chairman and board of directors on their annual tour. This can be a fraught exercise as these captains - and the odd captainess - of industry grill you on why you haven't done better. In the case of the Fairfax board, they are heavy hitters, all from Australia, who are as tough as old leather and have a fine ear for flim-flam. You don't want to bullshit them.

What the editor puts in the paper is their call, within statutory constraints that we work under, but that doesn't mean you may not be called upon to explain. When the board came through a couple of months ago I detailed the significance of the Nicholas story and how it was still being played out.

Bear in mind this is a board that has been extremely aggressive in online development. Last month it moved the Sydney operation to a new building in Pyrmont on Darling Harbour that includes a state of the art newsroom of the future. I was lucky enough to go and look at that a couple of weeks ago, just two days before they moved in. It features a central command hub with the various teams such as digital, news, business, sport radiating off it to encompass all 440 editorial staff on the floor. There is also a free-standing studio, with a fixed camera that reporters slot into to deliver breaking news, and two enclosed studios and editing facilities, as The Sydney Morning Herald moves to produce three half-hour live online news bulletins throughout the day.

This is also a board that approved the $\$ 750$ million purchase of [online auction house] TradeMe by chief executive David Kirk and changed its company name to Fairfax Media to signal that we are no longer solely a newspaper company, that we are a news company in all its forms.

So you can see that Fairfax has become a company despite its great mastheads steeped in history like The Age in Melbourne, The Sydney 
Morning Herald, The Press in Christchurch and The Dominion Post in Wellington, very much focused on an electronic future.

So it was hugely gratifying to have chairman Ron Walker, former Lord Mayor of Melbourne, a man who oversaw Australia's successful bid to the 2000 Sydney Olympics, ask whether I thought the Louise Nicholas story would have had the same impact and the same outcome if it had been solely web-based.

The answer in my opinion is clearly not. Ron Walker agreed. The power of print remains undiminished.

\section{Two other stories}

Look at the district health board Capital and Coast investigation that we published in December. This was the result of a two-year investigation into mishaps at the hospital. It involved extensive use of the Official Information Act and two appeals to the Ombusdman. We put together a detailed investigation within hours of that being published. Chief executive Margot Mains had resigned early, there was debate in the House, and there a rescue package was about to be announced that may well see the chair of the board's position under threat as well. Although she remains on the board, the chairperson was subsequently replaced with a new chairperson.

Look at the Act party MP Donna Huata fraud story we also broke. Week after week, in seven front-page leads we provided exquisite detail on the ways Donna and her husband Wi had defrauded us while they were supposed to be selflessly teaching poor Maori children how to read. Private-school fees, a stomach-stapling operation, art work, personal expenses, private phone calls -you name it, we collectively paid for it.

As a result of our investigative journalism, Donna Huata, a former high-flying MP, was expelled from the Act party, I remember [then Act MP] Ken Shirley telling me later, 'We always knew she was like that.' Huata was later convicted and jailed.

\section{The terrorism file}

In December 2007, we had another exclusive front-page lead that set the news agenda and will reverberate for some time yet. [The Dominion Post published extracts of the police affidavit on alleged terrorist activity in New Zealand]. This is a dramatic front page, certainly our strongest since 
Louise Nicholas. The content is compelling. It speaks to readers. It says this is what all the fuss is about. This is the secret police evidence, drawn from a 156-page affidavit that was presented to the court to get permission to arrest alleged terrorists across the country.

The arrests were made but in the information vacuum that followed it looked as if the police had totally over-reacted, that they were racist in picking on a bunch of largely Maori who were quite harmless, and the whole country wondered what was going on. As I read this affidavit it became quite clear the police had good cause to act, based on the enormous amount of intelligence they had gathered from electronic eavesdropping and from intercepting phone calls and texts.

I have agonised over some of the big calls, like Louise Nicholas, literally lying awake staring at the ceiling. But this one was quite clear cut. How could we be in contempt when the situation was so confused? The government's top legal adviser, Solicitor-General Dr David Collins, had ruled the law was so obscure and so badly written that terrorism charges should not be laid. That leaves less serious charges such as firearms offences.

Our publication was highly unlikely to affect trials that may be as much as 12 months away and judges and juries in this country are traditionally seen as being independent and robust enough not to be unduly influenced by media coverage. And, most importantly, we elected to remove the names from the police evidence that clearly showed people with access to weapons discussing targets and training for subversive acts against the state.

So, we took legal advice, and that was encouraging enough to give us the licence to proceed. It was along the usual lines: 'There is risk but on balance we think you can get away with it, but it will be on your head. Invoice to follow.'

Unfortunately, the Solicitor-General has taken a dim view of our action and invited us to explain why we shouldn't be charged with contempt. We have responded to that and await his pleasure. As political columnist Jane Clifton noted in the NZ Listener, with some pleasure I might add, it would be ironic if the editor and journalist concerned ended up in jail and the so-called terrorists got off.

In the digital age, we gave a lot of thought as to how best to maximise such a big story. Adapting to the web has been a big challenge for old-school journos like me with ink in our veins - and I still have some reservations - but 
you will see we have made some big strides and are making good progress towards having the best of both worlds. In the case of the police affidavit, we did consider putting the whole document online but decided-wisely as it turned out - that this would be too provocative and might expose us to too much legal risk. Since that time the affidavit has been posted on the web, through a US-based site, but was soon taken down. But it has gone up again and as far as I am aware it is still there.

There was some discussion in our editorial executive about limiting copy we put online, in a bid to boost our casual sales. But it's too late for that approach - the world has moved on. If we didn't carry the full story online, some other site would, and based on experience they probably wouldn't even credit us. So, we elected to go with top layout and put the whole story online as well.

And we got a terrific boost in both areas. Our casual sales were up 3000 on the day. We had alerted our circulation department and they had staff going round topping up supplies where outlets sold out. And our hits that day on dompost.co.nz were 150,000 . That was more than double our previous highest. That helped drive our monthly hits or page impressions to well over a million for the second month running, a target we were aiming at achieving by June next year. We now think we might be able to do two million by then. That's small beer, I know, compared with other sites but we think we are well underway. It is that sort of result that makes us feel this is a wonderful time to be in journalism. How exciting to be at the centre of such fundamental change.

That feeling is reflected internationally. A survey of 435 newspaper editors worldwide in 2007 by the World Editors Forum found they overwhelmingly - 85 percent - see a rosy future. I am firmly in that camp. The great challenge is to make that transition towards online journalism without dismissing editorial quality.

It is a demanding time as old, long-established methods are under threat and we are still stumbling our way towards the most effective next model. We have more readers than we've ever had but at the same time we are seeing our official, audited circulations and readerships of the printed product slowly declining. Our papers are still very profitable, TradeMe is more than achieving its profit targets, and the web is starting to pay its way.

Fairfax is doing better than many media companies in this regard, in that Digital's contribution to the overall profit has grown from one percent to 
14 percent in two years, according to chief executive David Kirk. As yet, there are no paid ads on our Dompost site, although there are on the overall Fairfax site, stuff. What a way we have come in the 100 years since The Dominion was launched in 1907.

\section{One hundred years of The Dominion}

For those of you who haven't seen it, this is the centenary publication we put out on our birthday on September 26, The Dom: A century of news. The wonderfully evocative image on the front taken in 1959 shows so much that has changed or has disappeared. At 59,000 this was the biggest ever crowd at Athletic Park sports stadium. They came to see the British Lions. The Health and Safety Nazis would have a fit at such a gathering today. Where are the handrails?

The trams are long gone, of course. They disappeared five years later in 1964. The wind tunnel that was Athletic Park saw its last game a decade ago and is now given over to housing. The Mobilgas brand has gone and we've long since stopped referring to miles per gallon. Griffin's biscuits, advertised on the tram, are no longer baked here. And rugby does not have the hold on the public imagination that it did in the 1950 s, not least because we're a bunch of chokers when it comes to the World Cup.

When The Dom was launched, the old country still dominated life in a raw new land where the natives lived almost exclusively in the country and were thought to be a dying race. Tragedy, death and loss of innocence lay ahead - in the trenches in France and Belgium and at Gallipoli. Pestilencethe great influenza epidemic - followed. There was hunger and hardship in the depression and more death and destruction in another world war. Through it all New Zealand began to form a unique character, bolstered by the optimism and booming times of the 1950s and 1960s and the migration of Māori to the cities. The capital's morning daily, The Dom, entwined itself around all these events, and many more. It became an integral part of peoples' lives, surviving and prospering even in the television age, just as it had through the advent of radio.

The economy was transformed in the 1980s and a distinct Pacific culture began to emerge, with an independent foreign policy that cut old ties. The Dominion underwent a revolution, too, when it merged with its sister paper, the 137-year-old Evening Post, in 2002. The bigger combined newspaper has 
gone from strength to strength, proudly championing its community as it held and built its lifeblood of circulation and advertising and readership.

\section{The online Dom}

So will the Dom survive another century in a rapidly changing world? What will our successors say as they mark 150 and then 200 years? One thing is certain - the publication will be markedly different from today. It will be delivered electronically to touch screens, phones, watches, and computers. Much of it will be tailored to individual interests and endless different editions. Our presses will still roll but the newspapers may well be smaller, more colourful, more interactive and easier to handle. Newspapers will talk to you in any number of languages and lead into all aspects of life. News will be delivered across a wide range of platforms by the minute throughout the day and the night.

We have just launched a digital edition, the entire paper online. That includes stories read to you in 12 languages. Our primary focus will continue to be local news, that is our point of advantage, but you will also see more campaigning journalism and more emphasis on features.

There will be big-story coverage too. Global warming, terrorism, wars, nuclear proliferation, depletion of resources, overpopulation, space exploration and technology will feature strongly. And we will surely report another major step in New Zealand's development and independence - an affectionate, but overdue, farewell to the monarchy and the formation of a republic.

And much of that will be reported online as breaking news. We can now do what radio and television have always done, that is, present news as it is happening. There is a lot of tosh talked about this heralding the end of newspapers. If any sector of the media should be really worried, it is television. Already they are looking askance at us as we line up beside them in court and at press conferences to take some simple video footage and put it online.

We were the first to break the news that Graham Henry had been reappointed the coach of the All Blacks and we beat the Herald by five minutes (we talk in those terms these days). We followed that up with our two main rugby writers Jim Kayes and Toby Robson standing in our newsroom giving some comment on it.

Why bother rushing home to watch the 6 o'clock news, for those who have the luxury of finishing work by then, when you've already seen what 
interests you? And as broadband penetration increases into homes, online use is shifting from office hours into evening leisure hours, where it threatens television, just as television altered the way people consume news by killing off afternoon papers.

\section{Populism}

There is one certainty with media and that is that it always fractures. We may be accessing news in 20 years in ways we can't even conceive of today. Whatever the format, we will prosper as long as we reflect what our community, what our readers, are interested in. And in that vein there is nothing wrong with being populist. It is beholden on us to be successful and that means being profitable and that in turn means being able to pursue good journalism and have the staffing resources to do that.

In August there was a journalism summit in Wellington - organised by the Engineering, Print and Manufacturing Union (EPMU). The union represents a minority of journalists these days but good on them for being proactive in this matter. Where I part company with them is over their professed concern about celebrity personality-driven news to sell newspapers. 'Profit' is not a dirty word and journalists, and I would suggest some tutors, need to get real.

'In order to make a dollar, we see Paris Hilton on the front page rather than a serious news story,' said the union's media industry council convenor Brent Edwards, who, amazingly, is also Radio New Zealand's political editor (no conflict there). 'How is that serving the public?', he went on. 'This woman doesn't affect the lives of people in New Zealand.'

What pomposity. If that's your yardstick then you wouldn't have David Beckham on the front page either and turn him into a poster, which The Dominion Post recently did. Of course Paris Hilton is a pantyless airhead but if she gets sentenced to 40 days in jail then that is news in my book. And, according to Google's 2007 survey of New Zealand users, it was Paris Hilton that drew more search engine traffic than anyone else. If you want to be worthy and dull, then you will go out of business and how will that serve the greater good of journalism?

What you can and must do is offer a mix of news in all its forms and entertainment. We're in show business where our front page is the box office. We do want to sell more newspapers and make no apology for that. If that means both quality investigative journalism and Paris Hilton or David Beckham on page one, then so be it. One does not preclude the other and in some ways they support each other. 


\section{The mix of online and print}

One of the beauties of being small and remote as we are is that you can see tsunamis coming before they strike. There are some scary trends in the United States in particular, where some print circulations are in free fall, but innovative newspaper organisations are reaching more readers than ever before. Traditional newspapers are still generating a lot of money, are still the number one advertising choice and at the same time the new media can, and is, making money. This was the thrust of the Pacific Area Newspaper Publishers' Association (Panpa) conference in Melbourne in August. Globally, newspaper circulations are up but there is no doubt the printed newspaper needs to rethink itself as it becomes more of a niche product, just one way to touch the news consumer.

The print market is not going to die off overnight, our presses will still wear out but it is changing. A recent Merrill Lynch report estimated that even if the current rapid online growth continues, it will be at least 20 years before online represents more than 50 percent of newspaper advertising revenues. While online is the rapidly growing market, print will remain the main profit centre well into the future- - even as circulation declines.

But we need to manage that. It makes no sense to provide free online the kind of detailed analysis and comment (and good writing) that print can make good money from. It also makes no sense in breaking 'exclusive' news stories online if there's a commercial advantage in breaking them in the paid for print paper.

Why would people buy a print paper if they've read exactly the same material on the web? Why set out a lovely, enticing smorgasbord and invite everyone to eat it for free? By all means let them have a prawn cocktail as a taster but not the whole banquet.

Former managing editor of The Observer John Duncan put it this way: 'It's barking mad to feed the internet rottweiler.' But The Washington Post sees it differently. They have totally embraced journalism on the web and their 10 principles include: 'We will publish most scoops and other exclusives when they are ready, which often will be online'.

And: 'Post journalism published online has the same value as journalism published in the newspaper. We embrace chats, blogs and multimedia presentations as contributions to our journalism.'

There is no magic bullet, no one size fits all, but my own view is the best approach - and one we pursue on The Dominion Post - is one somewhere 
between the extremes of the antagonism felt by The Observer's John Duncan and the drop-your-pants attitude of The Washington Post. We do have an integrated newsroom. Our web editor sits next to the chief reporter and they discuss early on each day what breaking stories we will put online, how we will cover them, whether we will film it, whether we want an audio grab, a picture gallery.

Stuff, Fairfax's national site, also sits in our newsroom, we generate the majority of their content and they attend our afternoon news conference. We do protect exclusive content. That is a wide definition that covers not just blockbusters that we may have spent weeks on but everything from district court to council where we are the only media present.

\section{Managing the change}

As far as expectations on staff in this time of great change, we elected to proceed gently. If anyone flatly refused to report for the web, it was not our intention to hit them over the head and demand they did. But if they did take such an approach, they would be effectively sidelining themselves and stood to be left behind.

The attitude of the print union was interesting when we negotiated the latest collective earlier this year. We thought they would come at us demanding more money to learn new skills. They were extremely progressive. Their concern was not that their members had to learn new skills. It was that they wanted training and did not want to be left behind.

And just as you assign reporters and writers according to their strengths, we always recognised that some would have greater aptitude than others and it was up to us to encourage and develop that. We are still in early days and I admit some of our efforts may have been a bit amateurish but that's not necessarily a bad thing. You don't necessarily need top line production. A graininess and a more natural approach sits well with the urgency of news.

The photographers, being visually driven, in particular have embraced the web and are doing some classy things with picture galleries. The reporters are pretty enthusiastic too and have proved very adaptable. The group that is the most apprehensive is the subeditors. They are generally older, set in their ways and some feel their jobs are disappearing.

My response is we will always need subeditors. Their jobs aren't disappearing but they are changing. Today's subeditor is tomorrow's web 
editor in a lot of cases. We will still need people to shape and edit copy, whether it is in print or online.

We see a pattern developing in the technology of the communications revolution:

1. mobile to alert me,

2. internet to tell me the detail,

3. television/internet video to show me/entertain me,

4. print to explain it, give it context and comment on it.

The newspaper companies that have made the new media transition most successfully are using all these forms, with constant cross-promotion between them.

As for blogs, to be honest, I don't know quite what to make of them. We are there. We have a number on our site and try to use them to link back to the paper. You do need to be careful you don't put too many up, that you don't have too much clutter, and also that you don't ask too much of your reporters. You don't want them torn between updating the web and blogging to such an extent they can't fulfil their primary function of writing for the newspaper.

Social media is in its infancy. It includes YouTube, Facebook, Bebo, and Myspace. Blogs generally have little news credibility and they use up news consumers' limited time. But on the upside there is significant potential for classified advertising on them.

\section{Coping with complaints}

One thing that doesn't change is that you don't get to be an editor without developing a thick skin and you need to vigorously defend your patch. The editor's role is best defined as the person who comes behind the elephant with a bucket. And sometimes the bucket overflows. My predecessor, a wily political operator, had a tried and true method of dealing with complainants: He would take them to lunch.

Feisty little Paul Holmes, then the doyen of talkback television, once took him to task in his typically foul-mouthed way. The then editor heard him out before suggesting a private lunch at a corner table in his favourite restaurant. 'Eff that!' shouted Holmes. 'I want to sit in the window where I can be seen.'

My liver isn't up to such an approach, my technique is to send the aggrieved a gift. It is a book of cartoons that we published several years ago 
by a well-known former evening post cartoonist named Nevile Lodge. They are gentle cartoons from a distant age - and it's amazing how effective this is. A polite accompanying letter asks the recipient to accept the gift with my compliments in the hope it will improve their mood. And it pretty well always does.

My favourite response is from an elderly man in Napier. He wrote back: I can assure you I am not aggrieved but I simply object to being misled by university trained, brain-washed Marxist journalists. You say you hope the Nevile Lodge cartoon book improves my mood. I have to tell you that since I convinced my lying, cheating, nagging ex-wife in 1992 that she should go and live with her immoral paramour instead of sneaking off to him and then lying about it I have never had a moment of sadness. I can confidently say that I am probably the healthiest and happiest pensioner on earth.'

\section{Relationships}

The longer I'm in this game the more I realise it is about relationships. It's about building trust and being open, generous in spirit, and hard as nails when it's needed. I once had a bureau chief at The Australian in Melbourne named John Monks. If I ever got het up about treatment of a story he would say 'It's only a game, lad.' And he's right. Journalism is a great game. It is a serious game but I imagine few other occupations offer such fun.

I'd like to leave you with a quote that really appeals to me. It is from a veteran US editor named Bill Kovach, who remains an idealist despite scars from battling management in defending his troops and from dealing with the internet onslaught. He believes the real quality of the news resides in the staff: 'Editors can shape and encourage things but the soul of journalism lies in each individual reporter.'

Tim Pankhurst edits Wellington's Dominion Post newspaper. He is also chairman of the Commonwealth Press Union's New Zealand section and its Media Freedom Committee. Tim Pankhurst and Phil Kitchin were awarded the 2008 Qantas Media Print Industry Award for Outstanding Achievement. tim.pankhurst@dompost.co.nz 


\section{Study leading \\ global}

communicators.

Then become

the ones that

will be heard.

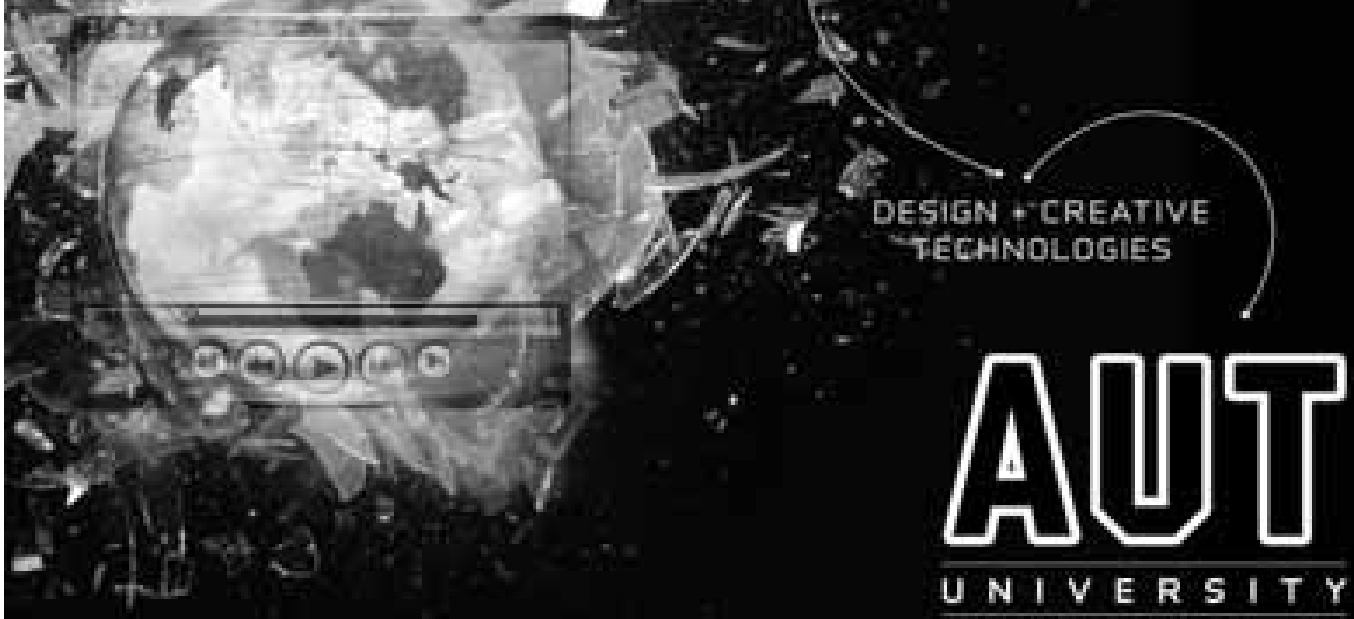

The University for the changing world WWW.AUTUNI.AC.NZ OR TXT "AUT' TO 466 